\title{
Vasopressin-mediated Forearm Vasodilation in Normal Humans Evidence for a Vascular Vasopressin V2 Receptor
}

\author{
Alan T. Hirsch, Victor J. Dzau, Joseph A. Majzoub, ${ }^{\star}$ and Mark A. Creager \\ Division of Vascular Medicine and Atherosclerosis and ${ }^{*}$ Division of Endocrinology, Brigham and Women's Hospital \\ and Harvard Medical School, Boston, Massachusetts 02115
}

\begin{abstract}
Arginine vasopressin (AVP) is a potent vasopressor and antidiuretic neurohormone. However, when administered intravenously to humans, AVP causes forearm vasodilation. This effect has been attributed to sympathetic withdrawal, secondary to AVP-induced sensitization of baroreceptors. The possibility that AVP also causes forearm vasodilation directly has not been examined.

Accordingly, the direct effect of AVP was determined by studying the forearm blood flow (FBF) response to intraarterial (IA) AVP infusion (0.01-1.0 $\mathrm{ng} / \mathrm{kg}$ per min). Infusion of IA AVP increased FBF (96\%) in the infused arm, but not the control arm, in a dose-dependent manner. The role of specific AVP V1 receptors in mediating this FBF response was determined before and after pretreatment with a V1 antagonist (AVP-A). AVP-A alone had no effect on FBF, but coadministration of AVP and AVP-A potentiated the vasodilatory response (223\%). IA infusion of the V2 agonist, 1-desamino[8-Darginine] vasopressin, caused a dose-dependent increase in FBF. These findings suggest that AVP causes direct, dose-dependent vasodilation in the human forearm that may be mediated by $\mathrm{V} 2$ vasopressinergic receptors. In contrast, AVP infusion caused digital vasoconstriction that was blocked by AVP-A, whereas dDAVP did not affect digital blood flow. Thus, AVP induces regionally selective vascular effects, with concurrent forearm vasodilation and digital vasoconstriction.
\end{abstract}

\section{Introduction}

Arginine vasopressin (AVP) ${ }^{1}$ is a neurohormone with potent vasopressor and antidiuretic properties (1). AVP is an arterial vasoconstrictor when studied in vitro or in animal preparations $(2,3)$. This vasoconstriction is mediated by a specific AVP receptor subtype, the $\mathrm{V} 1$ receptor, which increases intracellular calcium levels. The renal hydroosmotic effects of AVP

Address reprint requests to Dr. Mark A. Creager, Division of Vascular Medicine and Atherosclerosis, Brigham and Women's Hospital, 75 Francis Street, Boston, MA 02115. 1989.

Received for publication 12 July 1988 and in revised form 13 March

1. Abbreviations used in this paper: AVP, arginine vasopressin; DBF, digital blood flow; DBP, diastolic blood pressure; dDAVP, 1-desamino[8-D-arginine] vasopressin; FBF, forearm blood flow; HR, heart rate; MAP, mean arterial pressure; SBP, systolic blood pressure; 6keto-PGF $1 \alpha$, the 6-keto- $F_{1} \alpha$ metabolite of $\mathrm{PGI}_{2}$.

J. Clin. Invest.

(C) The American Society for Clinical Investigation, Inc.

0021-9738/89/08/0418/09 \$2.00

Volume 84, August 1989, 418-426 are mediated by a second receptor subtype, the V2 receptor, that increases intracellular cAMP. Vasopressin may also have vasorelaxant properties that belie its name. Several studies have suggested the existance of extrarenal V2 receptors that may mediate a vasodilatory effect of AVP (4-7). In addition, AVP may have variable effects on the sympathetic nervous system. AVP directly augments nerve terminal release of norepinephrine (8), but also causes withdrawal of sympathetic tone via sensitization of baroreflexes (9-14). Other evidence suggests additional mechanisms that might contribute to an AVP-mediated vasodilator effect; AVP increases release of vasodilator prostaglandins in vitro and in animals (15-17), causes release of endothelium-dependent relaxant factor(s) (18), and decreases renin secretion (19-22).

The role of vasopressin in supporting the blood pressure of humans remains unclear. Plasma AVP levels increase in response to orthostasis, hypotension, dehydration, exercise, nausea, and are elevated in some patients with congestive heart failure (23-30). AVP is a potent splanchnic vasoconstrictor (31), but when infused intravenously into normal subjects at high physiologic doses (achieving plasma levels of 200-300 $\mathrm{pg} / \mathrm{ml}$ ), the expected rise in blood pressure is either absent or quite modest $(32,33)$. Aylward and co-workers recently demonstrated that forearm blood flow (FBF) increased in normal subjects in response to intravenous AVP administration but interpreted this response to be due to systemic baroreceptor sensitization and withdrawal of sympathetic activity (32). This was supported by additional studies in humans that demonstrated, by direct nerve recording, that sympathetic activity decreased during intravenous infusion of vasopressin (11, 12). These authors did not test the possibility that the vasodilation also may have resulted from a direct vasorelaxant effect of AVP.

Accordingly, the objectives of the present investigation were: $(a)$ to determine the direct vascular effect of AVP in the human forearm independent of reflex effects by measuring the FBF response to local IA AVP infusion compared with that in the noninfused arm; $(b)$ to clarify the role of specific AVP receptors in mediating these vascular effects via either coadministration of a specific V1 vasopressin receptor antagonist or by infusing dDAVP, a vasopressin V2 receptor agonist; (c) to relate local changes in vasodilator prostaglandin levels to changes in FBF during AVP infusion; and $(d)$ to determine whether AVP's vascular effects were regionally selective by measuring blood flow to the finger as well as to the forearm.

\section{Methods}

Subjects. 22 normal volunteers, 13 males and 9 females, were studied in three protocols. The age of the subjects was $26 \pm 5$ yr (mean $\pm S D$ ), ranging from 19 to $34 \mathrm{yr}$. All subjects underwent a screening medical history, physical examination, and laboratory testing, which included complete blood count, serum electrolytes, blood glucose, serum trans- 
aminases, blood urea nitrogen, and serum creatinine, to exclude cardiac, renal, or hepatic disease. The protocol was approved by the Committee for the Protection of Human Subjects of the Brigham and Women's Hospital, and each volunteer gave written informed consent.

Experimental protocols. Each subject was studied in the morning after an overnight fast. Alcohol, caffeine, and cigarettes were all prohibited within $12 \mathrm{~h}$ of the study. Under local anesthesia and sterile conditions, a polyethylene catheter was inserted into a brachial artery of each subject. Additional catheters were inserted into an antecubital vein in each arm. The vascular research laboratory was noise free and lights were dimmed. Room temperature was controlled at $22^{\circ} \mathrm{C}$. All subjects rested for at least $30 \mathrm{~min}$ after catheter placement to establish a stable baseline before data collection.

Three experimental protocols were performed. In the first protocol, the dose-response relationship of IA AVP and forearm blood flow was determined in seven normal subjects. To examine direct vascular AVP effects, the hormone was infused intraarterially. FBF responses were measured in the experimental arm and compared with those obtained in the contralateral, control arm. Heparinized normal saline (1.0 $\mathrm{U} / \mathrm{ml}$ ) was infused during all baseline periods. After establishment of a stable hemodynamic baseline, AVP was infused at 0.01, 0.1, 1.0, and $10 \mathrm{ng} / \mathrm{kg}$ per min dosages in sequential 20 -min study periods. The infusion rate was constant $(0.3 \mathrm{ml} / \mathrm{min})$ during all study periods in all protocols (Harvard Apparatus, S. Natick, MA). Blood for determination of plasma AVP and vasodilator prostaglandin concentrations was collected after $15 \mathrm{~min}$ of AVP infusion at each dose. The systemic hemodynamic and FBF response to AVP was determined 20 min after initiation of each infusion dose. Two additional subjects served as time and vehicle controls by undergoing an identical protocol with intra-arterial infusion of vehicle (chlorobutanol) alone.

In the second protocol, 10 additional normal subjects were studied in order to examine the systemic hemodynamic, forearm, and digital blood flow responses to IA AVP infusion alone and after pretreatment with a vasopressin $\mathrm{V} 1$ receptor antagonist $\left[\mathrm{d}\left(\mathrm{CH}_{2}\right)_{5} \mathrm{Tyr}(\mathrm{Me}) \mathrm{AVP}\right]$. This study used methodology identical to that used in the first protocol. Blood pressure, heart rate, and forearm and digital blood flow responses were determined during five sequential 20 -min study periods: (i) baseline, (ii) IA infusion of AVP at $1.0 \mathrm{ng} / \mathrm{kg}$ per min, (iii) a second baseline, $(i v)$ intravenous administration of $0.5 \mathrm{mg}$ of the $\mathrm{V} 1$ AVP antagonist alone, and (v) rechallenge with AVP at $1.0 \mathrm{ng} / \mathrm{kg}$ per min during V1 AVP receptor blockade.

In the third protocol, the systemic hemodynamic, forearm, and digital blood flow dose-response relationship to IA administration of the V2 agonist 1-desamino[8-D-arginine] vasopressin (dDAVP) was determined. dDAVP was administered at $0.01,0.1$, and $1.0 \mathrm{ng} / \mathrm{kg}$ per min doses in sequential 20 -min periods. This protocol was performed in five subjects, two of whom had participated previously in the first or second protocols.

Drugs used. Synthetic arginine vasopressin (Pitressin; Parke-Davis, Inc., Morris Plains, NJ) was diluted in heparinized normal saline for IA administration. The AVP V1 receptor antagonist studies were performed using d $\left(\mathrm{CH}_{2}\right)_{5}$ Tyr(Me)AVP (kindly provided by Dr. Karl Hofbauer, Ciba-Geigy A. G., Basel, Switzerland). dDAVP (desmopressin acetate, USV Laboratories, Inc., Tarrytown, NY) was diluted in heparinized normal saline before IA administration. Commercially available AVP and DDAVP are both supplied in solution with a preservative agent, chlorobutanol (1,1,1-trichloro-2-methyl-2-propanol). Crystalline chlorobutanol was purchased from Sigma Chemical Co. (St. Louis, MO), and reconstituted with sterile saline to the concentration of the commercial Pitressin. Before parenteral administration, serial dilutions were performed as for active drug.

Hemodynamic measurements. The brachial artery catheter was connected to a transducer (model P23D; Gould, Inc., Cleveland, OH), with zero reference estimated to be $5 \mathrm{~cm}$ vertically beneath the sternal angle of Louis. Systolic and diastolic blood pressure (SBP and DBP, in millimeters of mercury) were the mean of 10 cardiac cycles in each study period. Mean arterial pressure (MAP, in millimeters of mercury) was derived electronically from the phasic blood pressure recording.
Brachial artery blood pressure and a lead II electrocardiographic trace were recorded on a strip chart recorder (Model 4600; Gould, Inc.). The heart rate (HR, beats/minute) was calculated from the mean $R-R$ interval of ten cardiac cycles.

Forearm and digital blood flow measurements. FBF (in milliliters/ 100 milliliters per minute) and digital blood flow (DBF; milliliters/100 milliliters/minute) were measured by venous occlusion strain gauge plethysmography, using calibrated mercury-in-silastic strain gauges (D. E. Hokanson, Inc., Issaquah, WA). Bilateral forearm strain gauges were placed $5 \mathrm{~cm}$ distal to the antecubital creases of each arm, with each arm supported above right heart level. The finger strain gauge and venous occlusion cuff were placed immediately distal and proximal, respectively, to the proximal interphalangeal joint on the second digit of the experimental arm. Forearm and digital venous occlusion pressures were both $40 \mathrm{mmHg}$. When both DBF and FBF were measured, DBF was determined first. Circulation to the hand was then arrested by inflating a wrist cuff to suprasystolic pressures for $1 \mathrm{~min}$ before each FBF determination. Each forearm and digital blood flow determination comprised at least five separate measurements performed at 10-15-intervals.

Hormonal measurements. Antecubital venous blood was collected into heparinized tubes, immediately placed on ice, and centrifuged at $2^{\circ} \mathrm{C}$. The plasma was separated and stored at $-70^{\circ} \mathrm{C}$ before assay. Plasma AVP was measured in plasma extracts in triplicate using a commercial polyclonal antibody (Arnel Pharmaceuticals. New York, NY) at a final dilution of 1:75,000 AVP standard (Bachem, Torrence, CA) and $\left[{ }^{125} \mathrm{I}\right]$ arginine vasopressin (New England Nuclear, Boston, MA) as previously described (33). The assay has a sensitivity of 0.2 $\mathrm{pg} /$ tube,$<0.005 \%$ cross-reactivity with oxytocin, $100 \%$ cross-reactivity with the $\mathrm{V} 1$ receptor antagonist, and an intraassay coefficient of variation of $9 \%$.

The vasodilator prostaglandin $\mathrm{PGE}_{2}$ and the $\mathrm{PGI}_{2}$ metabolite, 6keto-PGF $\alpha$, were determined in unextracted plasma extracts from forearm venous effluent by RIA as described (34). In this radioim-

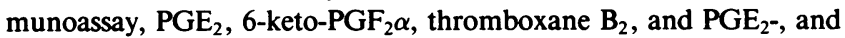
$\mathrm{PGF}_{2} \alpha-\mathrm{M}$ cross-react $<1 \%$. These prostaglandin assays have a sensitivity of $10 \mathrm{pg} / \mathrm{ml}$ and intraassay coefficient of variation of $<10 \%$.

Statistical analysis. Forearm and digital blood flow, blood pressure, heart rate, and hormonal data are presented as mean \pm SE. Data from each study period were compared by analysis of variance for repeated measures for parametric data, followed by Neuman-Keuls posthoc testing for statistical significance. Friedman's analysis of variance for repeated measures was used for nonparametric data. Statistical significance was accepted at the $95 \%$ confidence level $(P \leq 0.05)$.

\section{Results}

Protocol 1: IA AVP dose-response relationship. Table I displays the systemic hemodynamic response to incremental doses of intraarterial AVP. There were no significant changes in systolic or diastolic blood pressure at any AVP dose. Heart rate

Table I. Systemic Hemodynamic Response to Incremental IA Infusion of AVP in Normal Subjects (Protocol 1)

\begin{tabular}{lrrrrr}
\hline & \multicolumn{5}{c}{ AVP Dose (ng/kg per min) } \\
\cline { 2 - 6 } & \multicolumn{1}{c}{0} & \multicolumn{1}{c}{0.01} & \multicolumn{1}{c}{0.1} & \multicolumn{1}{c}{1.0} & \multicolumn{1}{c}{10} \\
\hline SBP (mmHg) & $138 \pm 7$ & $143 \pm 7$ & $141 \pm 7$ & $139 \pm 6$ & $134 \pm 6$ \\
DBP (mmHg) & $69 \pm 4$ & $72 \pm 3$ & $73 \pm 3$ & $74 \pm 3$ & $68 \pm 4$ \\
HR (beats/min) & $60 \pm 6$ & $58 \pm 3$ & $58 \pm 3$ & $60 \pm 3$ & $66 \pm 2^{*}$ \\
\hline
\end{tabular}

Abbreviations: SBP, systolic blood pressure; DBP, diastolic blood pressure; HR, heart rate.

* $P<0.05$ compared with baseline. 


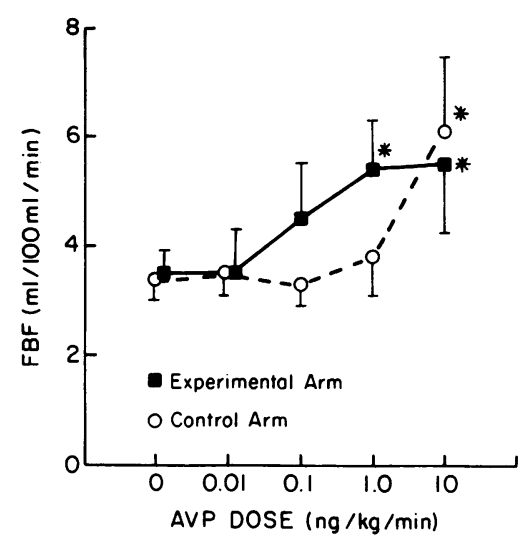

Figure 1. The dose-response relationship of forearm blood flow to IA AVP administration in normal subjects. Data are presented as mean \pm SEM. ${ }^{*} P<0.05$ compared with baseline.
Table III. Plasma AVP Levels in the Experimental and Control Arms during Incremental IA AVP Infusion in Normal Subjects (Protocol 1)

\begin{tabular}{lccccc}
\hline & \multicolumn{5}{c}{ AVP Dose (ng/kg per min) } \\
\cline { 2 - 6 } & 0 & 0.01 & 0.1 & 1.0 & 10 \\
\hline Arm & & & & & \\
E $(p g / m l)$ & $3.1 \pm 1.2$ & $21 \pm 12$ & $67 \pm 16^{*}$ & $261 \pm 55^{*}$ & $2,584 \pm 738^{*}$ \\
C $(p g / m l)$ & $2.7 \pm 0.4$ & $2.1 \pm 0.5$ & $3.2 \pm 0.7$ & $17 \pm 3.7^{*}$ & $228 \pm 38^{*}$
\end{tabular}

Abbreviations: E, experimental arm; C, control arm.

${ }^{*} P<0.01$ compared with baseline.

tion occurred only at the highest infusion dose and was associated with a comparable AVP level, $228 \mathrm{pg} / \mathrm{ml}$. Thus, intraarterial AVP administration elicited a dose-dependent increase in FBF in the experimental arm. This dose-dependent relationship was shifted to the right in the control arm.

Protocol 2: Effect of IA AVP after vasopressin VI receptor blockade. This protocol was designed to determine whether forearm vasodilation could be blocked by the vasopressin V1 receptor antagonist. After initial baseline values were recorded, AVP was infused intraarterially at the dose previously determined to cause maximal forearm vasodilation $(1.0 \mathrm{ng} / \mathrm{kg}$ per $\mathrm{min})$. Baseline conditions were reestablished, and the effects of intravenous administration of the V1 receptor antagonist alone were determined. Previous investigation has demonstrated that this $\mathrm{V} 1$ receptor antagonist has a duration of action of $>2 \mathrm{~h}$ (35). Thus, $\mathrm{V} 1$ receptor blockade should have persisted during subsequent rechallenge with AVP. Table IV displays the systemic hemodynamic response observed in this protocol. Systolic blood pressure was unchanged during all study periods. Diastolic blood pressure decreased by $6 \mathrm{mmHg}$ $(P<0.01)$ and heart rate rose by 15 beats/minute $(P<0.01)$ when AVP was infused during simultaneous V1 receptor blockade.

The forearm blood flow response in this protocol is depicted in Figs. 2 and 3. FBF was $2.3 \pm 0.2$ and $2.4 \pm 0.3 \mathrm{ml} / 100$ $\mathrm{ml}$ per min in the experimental and control arms, respectively, during the baseline period. FBF rose significantly to $4.5 \pm 1.1$ $\mathrm{ml} / 100 \mathrm{ml}$ per $\min (P<0.05)$ in the experimental arm during the initial IA AVP infusion. This vasodilator response was

Table IV. Systemic Hemodynamic Response to IA AVP Infusion Alone, to Intravenous Administration of a V1 Antagonist, and to Coadministration of $A V P$ during V1 Blockade in Normal Subjects (Protocol 2)

\begin{tabular}{|c|c|c|c|c|c|}
\hline & \multicolumn{5}{|c|}{ Dilutions per corresponding AVP dose ( $\mathrm{ng} / \mathrm{kg}$ per $\mathrm{min})$} \\
\hline & 0 & 0.01 & 0.1 & 1.0 & 10 \\
\hline $\operatorname{SBP}(m m H g)$ & $104 \pm 7$ & $106 \pm 2$ & $102 \pm 4$ & $101 \pm 2$ & $99 \pm 1$ \\
\hline \multicolumn{6}{|c|}{$\mathrm{FBF}(\mathrm{E})(\mathrm{ml} / 100$} \\
\hline ml per min) & $2.7 \pm 0.9$ & $2.6 \pm 1.0$ & $2.5 \pm 0.3$ & $2.4 \pm 0.5$ & $2.3 \pm 0.3$ \\
\hline \multicolumn{6}{|l|}{$\mathrm{FBF}(\mathrm{C})(\mathrm{ml} / 100$} \\
\hline ml per min) & $2.6 \pm 0.3$ & $3.1 \pm 0.6$ & $2.3 \pm 0.7$ & $1.9 \pm 0.6$ & $1.9 \pm 0.3$ \\
\hline
\end{tabular}

Serial vehicle doses were administered as per protocol 1 . Abbreviations: $\mathrm{FBF}(\mathrm{E} / \mathrm{C})$, forearm blood flow $(\mathrm{ml} / 100 \mathrm{ml}$ per $\mathrm{min})$ in experimental and control arms, respectively.

\begin{tabular}{lrrrrc}
\hline & \multicolumn{5}{c}{ AVP Dose (ng/kg per min) } \\
\cline { 2 - 6 } & 0 & 1.0 & 0 & $\begin{array}{c}0 \\
+ \\
\text { AVP-A }\end{array}$ & $\begin{array}{c}1.0 \\
+ \\
\text { AVP-A }\end{array}$ \\
\hline SBP (mmHg) & $131 \pm 6$ & $130 \pm 4$ & $132 \pm 7$ & $128 \pm 5$ & $127 \pm 6$ \\
DBP (mmHg) & $64 \pm 6$ & $64 \pm 5$ & $65 \pm 9$ & $63 \pm 8$ & $58 \pm 6^{*}$ \\
HR (beats/min) & $58 \pm 3$ & $63 \pm 3$ & $62 \pm 3$ & $66 \pm 2$ & $73 \pm 2^{*}$ \\
\hline
\end{tabular}

Abbreviations: AVP-A, AVP-(V1) antagonist. For other abbreviations, see Table I.

$* P<0.01$ compared with baseline. 


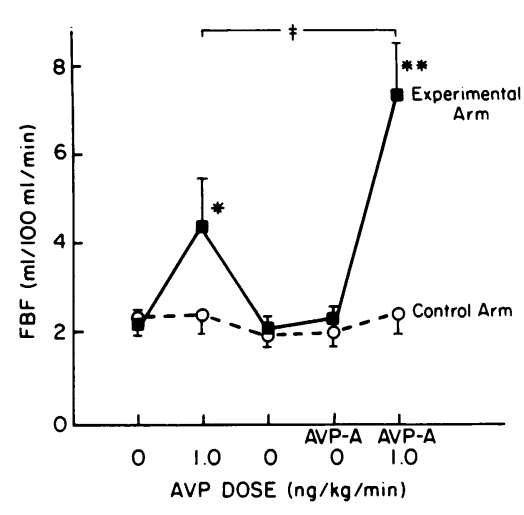

comparable to that obtained in protocol 1. Termination of the AVP infusion was associated with a prompt reestablishment of baseline FBF. Administration of the V1 antagonist alone did not change FBF in either arm. When AVP was then reinfused at the previous dose, the rise in FBF in the experimental arm was significantly greater than that noted during the previous AVP infusion (to $7.5 \pm 1.2 \mathrm{ml} / 100 \mathrm{ml}$ per min, $P<0.01$ ). In contrast, FBF was unchanged in the control arm with all interventions.

DBF was measured in the experimental arm in seven of these subjects (Figs. 3 and 4). DBF decreased significantly during AVP infusion (from $7.7 \pm 1.8$ to $3.6 \pm 0.9 \mathrm{ml} / 100 \mathrm{ml}$ per min, $P<0.05)$. Basal DBF values were reestablished after cessation of the AVP infusion. Administration of the AVP antagonist alone did not change digital blood flow $(5.9 \pm 2.0$ $\mathrm{ml} / 100 \mathrm{ml}$ per min, NS). After administration of the AVP antagonist, the vasoconstrictor response to the second AVP challenge was abolished $(6.4 \pm 2.7 \mathrm{ml} / 100 \mathrm{ml}$ per min, NS).

Bilateral forearm venous plasma vasopressin levels were determined in seven subjects during this protocol (Table V). Plasma AVP levels were determined at baseline, during AVP

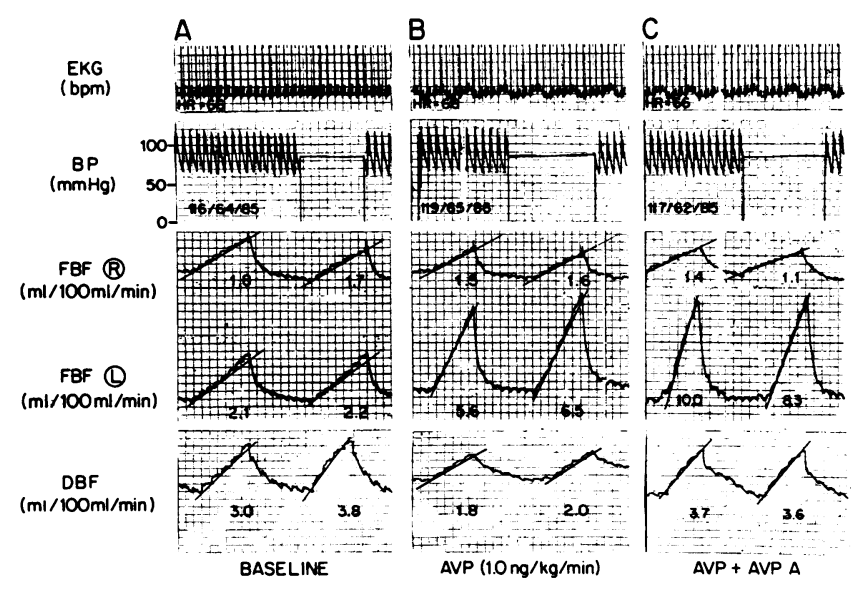

Figure 3. Representative data recorded during protocol 2. Tracing of the simultaneous EKG for heart rate (HR) determination, phasic and mean arterial pressure (BP), bilateral forearm blood flow (FBF), and digital blood flow (DBF) recorded during the $(A)$ baseline period, $(B)$ left brachial arterial AVP infusion at $1.0 \mathrm{ng} / \mathrm{kg}$ per min, and $(C)$ cotreatment with IA AVP and intravenous AVP-antagonist. DBF was recorded from the infused left arm.

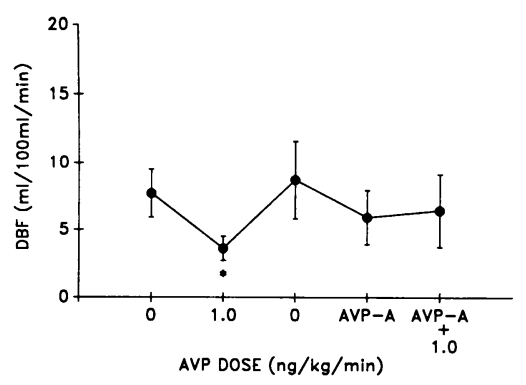

Figure 4. The DBF response in the infused arm during IA AVP challenge before and after administration of the AVP-antagonist. AVP-A, AVP V1-receptor antagonist. ${ }^{*} P$ $<0.05$ compared with baseline.

challenge, and during the second baseline before administration of the V1 antagonist. AVP determinations after administration of the V1 antagonist were not performed due to the $100 \%$ cross-reactivity of AVP and its methyl-tyrosine substituted analogue in this assay. Baseline plasma AVP concentrations were equal in both arms. In the control arm, AVP infusion at $1.0 \mathrm{ng} / \mathrm{kg}$ per min increased the venous AVP concentration to a comparable level $(P<0.01$ compared with baseline) as that measured in protocol 1. Plasma AVP concentration returned to control values during the second baseline period $(P=\mathrm{NS})$. In the experimental arm, venous AVP concentration rose to only $45 \%$ of that achieved during the serial AVP infusions of protocol 1 , but elicited a comparable increase in FBF. Additionally, despite the return of FBF to control values during the second baseline period, venous AVP levels remained slightly elevated $(P<0.05)$.

Protocol 3: $d D A V P-F B F$ dose-response relationship. Table VI displays the systemic hemodynamic response to incremental doses of IA dDAVP. There were no significant changes in systolic blood pressure in response to the lower two dDAVP doses, but SBP decreased significantly at the highest dose $(P$ $<0.05$ ). Diastolic blood pressure and heart rate were unchanged at all doses.

The FBF response to intraarterial dDAVP is displayed in Fig. 5. FBF was equal in both arms at baseline $(2.1 \pm 0.1$ and $2.3 \pm 0.3 \mathrm{ml} / 100 \mathrm{ml}$ per min, experimental and control arms, respectively). FBF increased significantly in the experimental arm at the $0.1-\mathrm{ng} / \mathrm{kg}$ per min dose (to $4.5 \pm 0.6 \mathrm{ml} / 100 \mathrm{ml}$ per min, $P<0.05$ ) and increased further at the $1.0-\mathrm{ng} / \mathrm{kg}$ per min infusion rate (to $8.8 \pm 2.4 \mathrm{ml} / 100 \mathrm{ml}$ per min, $P<0.01 \mathrm{com}$ pared with baseline). FBF in the control arm was unchanged at all infusion rates.

DBF was little changed during dDAVP infusion. Baseline DBF in the experimental arm was $5.8 \pm 1.9 \mathrm{ml} / 100 \mathrm{ml}$ per min, and 7.0 \pm 2.9 . 7.4 \pm 2.6 , and $5.4 \pm 1.6 \mathrm{ml} / 100 \mathrm{ml}$ per min, respectively during the $0.01-, 0.1-$, and $1.0-\mathrm{ng} / \mathrm{kg}$ per min $\mathrm{dDAVP}$

Table V. Plasma AVP Levels in the Experimental and Control Arms during Protocol 2

\begin{tabular}{ccccc}
\multicolumn{7}{c}{ AVP Dose $(\mathrm{ng} / \mathbf{k g}$ per $\min )$} \\
\hline \multirow{2}{*}{1.0} & 0 & $\begin{array}{c}0 \\
+\end{array}$ & $\begin{array}{c}1.0 \\
+ \\
\end{array}$ \\
& & & AVP-A & AVP-A
\end{tabular}

Arm

$\begin{array}{cccccc}\mathrm{E}(p g / \mathrm{ml}) & 4.2 \pm 0.7 & 117 \pm 10^{*} & 26 \pm 4^{\ddagger} & \mathrm{ND} & \mathrm{ND} \\ \mathrm{C}(\mathrm{pg} / \mathrm{ml}) & 5.2 \pm 0.8 & 20 \pm 3.9^{*} & 8.2 \pm 1.2 & \text { ND } & \text { ND }\end{array}$

For abbreviations, see Table III.

${ }^{*} P<0.01$ compared with baseline; ${ }^{\ddagger} P<0.05$ compared with baseline. 
Table VI. Systemic Hemodynamic Response to Incremental IA Infusion of dDAVP in Normal Subjects

\begin{tabular}{lrrrr}
\hline & \multicolumn{4}{c}{ dDAVP dose (ng/kg per min) } \\
\cline { 2 - 5 } & \multicolumn{1}{c}{0} & \multicolumn{1}{c}{0.01} & \multicolumn{1}{c}{0.1} & 1.0 \\
\hline SBP $($ mmHg $)$ & $130 \pm 5$ & $130 \pm 7$ & $130 \pm 7$ & $124 \pm 5^{*}$ \\
DBP $($ mmHg $)$ & $68 \pm 5$ & $68 \pm 3$ & $69 \pm 3$ & $67 \pm 4$ \\
HR (beats/min) & $54 \pm 1$ & $56 \pm 2$ & $59 \pm 2$ & $58 \pm 3$ \\
& & & & \\
\hline
\end{tabular}

For abbreviations, see Table I.

${ }^{*} P<0.05$ compared with baseline.

infusion dosages. The changes in DBF during dDAVP infusion are illustrated in Fig. 6. Whereas FBF increased in a dosedependent manner, DBF was unchanged at all infusion doses.

Vasodilator prostaglandin levels. Venous blood obtained from the experimental and control arms of seven subjects in protocols 1 and 2 was assayed for $\mathrm{PGE}_{2}$ and 6-keto-PGF $1 \alpha$ levels to determine the relationship of the vasodilator effect to changes in local prostaglandin concentrations (Table VII). At baseline, there was no significant difference in the $\mathrm{PGE}_{2}$ or 6-keto-PGF ${ }_{1} \alpha$ levels in the control and experimental arms. Vasodilator prostaglandin levels in the experimental and control arms did not change significantly from baseline whether assessed at the $1.0-\mathrm{ng} / \mathrm{kg}$ per min infusion dose or at the dose associated with peak forearm vasodilation.

\section{Discussion}

The potent vasoconstrictor effect of arginine vasopressin has been demonstrated in vitro (2) and during high dose infusion in animals $(21,36-38)$. In humans, however, only modest increases in blood pressure or systemic vascular resistance occur during AVP infusion $(22,31,32)$. Intravenous administration of AVP increases FBF (32). These discrepant physiologic effects have heretofore been attributed to species differences or to the withdrawal of sympathetic efferent activity by sensitization of baroreflexes. The present investigation demonstrates $(a)$ that AVP elicits dose-dependent vasodilation in the human forearm, $(b)$ that AVP-induced forearm vasodilation is a direct vascular effect, independent of systemic baroreflex responses, $(c)$ that the vasopressinergic $\mathrm{V} 2$ receptor may be responsible for the vasodilatory response, $(d)$ that AVP fore-

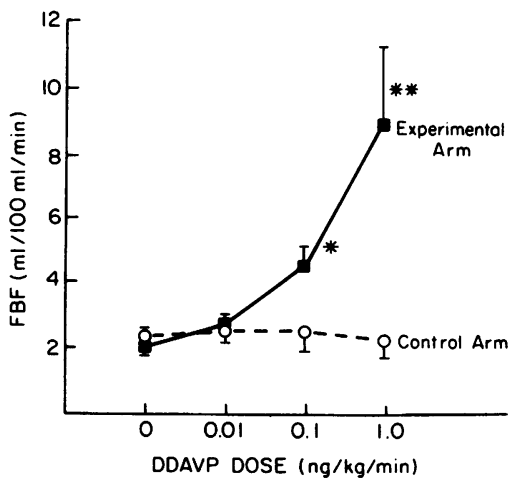

Figure 5. The dose-response relationship of FBF to IA dDAVP administration in normal subjects. Data are presented as mean \pm SEM. ${ }^{*} P<0.05$ compared with baseline. ${ }^{* *} P$ $<0.01$ compared with baseline.

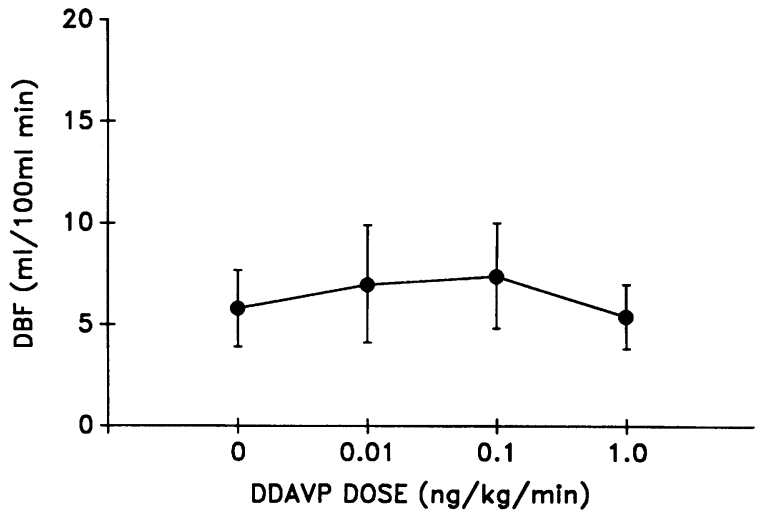

Figure 6. The DBF response in the infused arm to IA dDAVP infusion. No DBF determinations were significantly changed from baseline.

arm vasodilation is not a homogeneous effect, inducing regionally selective forearm vasodilation and digital vasoconstriction, and $(e)$ that infusion of AVP in a wide range of doses causes only minor net effects on blood pressure.

Vasopressin-induced forearm vasodilation in humans. Though two prior human studies have demonstrated that systemic AVP infusion increases limb blood flow, the direct vascular effect of AVP has not previously been demonstrated (32, 39). Kitchin et al. in 1957 (39), observed an increase in FBF during intravenous AVP infusion (at $\sim 6 \mathrm{ng} / \mathrm{kg}$ per min). These authors investigated this phenomenon further by intrabrachial artery AVP infusion, but failed to observe an increase in FBF; however, the IA infusion rate was low $(\sim 0.06 \mathrm{ng} / \mathrm{kg}$ per min). Similar infusion rates in our study also failed to change FBF. Aylward et al. recently assessed the forearm blood flow response to intravenous AVP infusion and lower body negative pressure in normal subjects. No change in FBF occurred when plasma AVP levels were raised to $24 \pm 4 \mathrm{pg} / \mathrm{ml}$ by a 0.4-ng/kg per min intravenous infusion, but FBF increased when plasma AVP rose to $290 \pm 41 \mathrm{pg} / \mathrm{ml}$ during a $4-\mathrm{ng} / \mathrm{kg}$ per min infusion (32). The reflex vasodilator response to withdrawal of lower body negative pressure was interpreted as documenting AVP-induced baroreceptor sensitization and withdrawal of sympathetic tone. This was based on direct measurements of nerve activity in humans showing a decline in

Table VII. Plasma PGE 2 and 6-keto-PGF $F_{1 \alpha}$ Levels in the Experimental and Control Arms at the $1.0 \mathrm{ng} / \mathrm{kg}$ per min AVP Infusion Dose, or at Peak Forearm Vasodilation in Seven Normal Subjects

\begin{tabular}{lccc}
\hline & \multicolumn{2}{c}{ AVP dose (ng/kg per min) } & \\
\cline { 2 - 3 } & 0 & 1.0 & $\begin{array}{c}\text { Peak } \\
\text { vasodilation }\end{array}$ \\
\hline $\mathrm{PGE}_{2}(p g / m l)$ & & & \\
$\quad \mathrm{E}$ & $308 \pm 55$ & $231 \pm 48$ & $261 \pm 46$ \\
$\mathrm{C}$ & $227 \pm 35$ & $185 \pm 27$ & $188 \pm 18$ \\
6-keto-PGF $\alpha(p g / m l)$ & & & \\
E & $107 \pm 11$ & $113 \pm 14$ & $106 \pm 11$ \\
$\mathrm{C}$ & $104 \pm 10$ & $114 \pm 14$ & $107 \pm 11$ \\
\hline
\end{tabular}

No interarm or intertreatment effects were statistically significant. For abbreviations, see Table III. 
sympathetic activity with intravenous vasopressin $(11,12)$ and experiments in animals showing sensitization of baroreceptors $(13,14)$. Thus, sympathetic withdrawal was presumed by the authors to be the cause of the forearm vasodilation observed during AVP infusion.

In this study, we elucidated an additional mechanism whereby AVP affects forearm vascular resistance. Forearm vasodilation occurred in the experimental arm in the absence of FBF changes in the noninfused arm, suggesting that the effect is a direct, not a reflex phenomenon. Furthermore, our results demonstrate that AVP-induced vasodilation is a dose-dependent phenomenon. Comparable forearm vasodilation was observed in each arm as plasma AVP levels increased; however, the dose-response curve of the control arm was shifted rightward compared with the experimental arm.

Evidence for a vascular vasopressin $V 2$ receptor. The synthesis of AVP antagonists by Manning et al. has been rapidly followed by their application as physiologic probes, yielding significant insights into the role of specific AVP receptors (40, 41). The V1 receptor is present on rat and human vascular smooth muscle (1) and mediates AVP-induced vasoconstriction. The V1 receptor antagonist used in this study has a V2/V1 receptor specificity of 1:30 compared with AVP. It has antivasopressor $\left(p \mathrm{~A}_{2}=8.62\right)$, in vivo antioxytocic $\left(p \mathrm{~A}_{2}\right.$ $=6.62)$, and weak $\mathrm{V} 2$ receptor agonist $(0.31 \mathrm{U} / \mathrm{mg})$ properties (42), and a markedly increased half-life compared with AVP $(35,42,43)$.

The V2 receptor has heretofore been localized in renal collecting ducts and mediates AVP antidiuretic affects via activation of the adenylate cyclase system. It has also been localized in brain, where its significance is unknown. Despite synthesis of vasopressin antagonists with high V2 receptor specificity in other mammalian species, no antagonist retains V2 specificity in humans. Thus, investigation of $\mathrm{V} 2$ receptor-specific physiologic effects in man is presently limited to use of V2 agonist peptides. 1-desamino[8-D-arginine] vasopressin, or dDAVP, is such an analogue characterized by slightly increased V2 receptor affinity (antidiuretic activity $=1,200$ $\mathrm{U} / \mathrm{mg}, 1.7$ times that of AVP) and greatly diminished V1 receptor affinity, (activity $=0.39 \mathrm{U} / \mathrm{mg}, 1 / 3,000$ th that of its parent peptide); overall, the $\mathrm{V} 2 / \mathrm{Vl}$ affinity ratio is $\sim 2,054: 1$ $(42,44)$. dDAVP also demonstrates a prolonged plasma halflife compared with AVP ( $t_{1 / 2}$ of $\left.\sim 55 \mathrm{~min}\right)(45)$

Despite advances in understanding receptor-mediated interactions of AVP with vascular smooth muscle, the physiologic effects of AVP in normal and pathologic states remains controversial. Systemic AVP infusion in conscious dogs increases mean arterial pressure and peripheral resistance, decreases cardiac output, and decreases skeletal muscle, pancreatic, mesenteric, myocardial, and cutaneous blood flow as determined by injection of radioactive microspheres $(46,47)$. Further study of the hemodynamic effects of infusion of AVP or its analogues, however, in animals has implicated a possible role of $\mathrm{V} 2$ receptors in causing regional or systemic vasodilation. Liard and co-workers recently demonstrated that intraaxillary arterial infusion of AVP in conscious dogs decreased skin and compact skeletal bone blood flow, but skeletal muscle blood flow was preserved (48). Administration of either 4-valine-8-D-AVP (VDAVP, a selective V2 agonist) or AVP during V1 receptor blockade decreases systemic vascular resistance and increases cardiac output $(4,6,38)$.
The physiologic significance of these findings has also been investigated. Dogs subjected to dehydration demonstrate increased plasma AVP levels ( $\sim 10 \mathrm{pg} / \mathrm{ml})$; in response to administration of a V1 antagonist, cardiac output and skeletal muscle blood flow increase (5). Plasma AVP also increases during hypovolemic hypotension in animals; administration of $\mathrm{V} 1$ receptor antagonist potentiates the hypotensive response to hemorrhage. These responses have been interpreted to suggest that $\mathrm{V} 1$ receptors mediate a significant pressor effect in these conditions (49-51). However, V1 blockade in these studies may have unmasked a significant $\mathrm{V} 2$ vasodilation effect.

As in previous studies, administration of a $\mathrm{V} 1$ receptor antagonist alone to normal subjects in this study was without significant effects on blood pressure or heart rate (35). The present study demonstrates further that blockade of the V1 receptor potentiates the forearm vasodilatory effect of intraarterially infused AVP (protocol 2). It is theoretically possible that pretreatment with the $\mathrm{V} 1$ receptor antagonist might have potentiated forearm vasodilation on the basis of partial V2 agonism. However, this is unlikely as there was no change in forearm blood flow in either arm despite administration of a pharmacologic dose of this peptide. AVP levels in the experimental arm did not return to control values during the second baseline period in protocol 2. Because this could be due to persistent tissue binding of AVP, it is possible that the AVP rechallenge was not a truly comparable vasodilatory stimulus. However, similar plasma concentrations of AVP $(\sim 26 \mathrm{pg} / \mathrm{ml})$ did not elicit any change in FBF in the initial dose-response protocol. Thus, it is likely that the augmented FBF after V1 receptor blockade was a V2 agonist effect. To confirm the hypothesis that AVP vasodilation is mediated by the V2 receptor, dDAVP, a highly specific V2 receptor agonist, was infused and induced similar dose-dependent forearm vasodilation. Thus, these data support the role of a probable V2 receptor in mediating forearm vasodilation. Further confirmatory support awaits the availability of a specific $V 2$ receptor antagonist for human use.

Other possible mechanisms of AVP-induced vasodilation. Other potential nonreceptor mechanisms could underlie the forearm vasodilation that has been observed. For example, AVP has been shown to increase synthesis and/or release of vasodilatory prostaglandins by the kidney (15-17). AVP-mediated release of $\mathrm{PGE}_{2}$ or $\mathrm{PGI}_{2}$ has not yet been shown to occur in vascular smooth muscle or the endothelium. We could detect no increase in these vasodilator prostaglandins from antecubital venous plasma during AVP-induced forearm vasodilation; this does not, however, rule out a significant local effect of these prostaglandins. Although venous prostaglandin concentrations did not change, total forearm blood flow was increased twofold, implying that net prostaglandin release may have similarly increased. Interpretation of prostaglandin concentrations in limb venous effluent is also complicated by the possibility that hand and skeletal muscle vasculature contribute differentially to the total $\mathrm{PGE}_{2}$ or $\mathrm{PGI}_{2}$ concentration in antecubital venous blood. More definitive evidence awaits demonstration that prostaglandin synthetase-inhibitor pretreatment fails to blunt AVP vasodilation.

Forearm vasodilation might also have been due to augmented release of endothelium-derived relaxant factor(s) (18) or interactions with central nervous system V2 receptors. Canine basilar and coronary arterial (but not femoral arterial) 
rings demonstrate endothelium-dependent relaxations in response to AVP, an effect that is blocked by the $\mathrm{d}\left(\mathrm{CH}_{2}\right)_{5} \mathrm{Tyr}(\mathrm{Me}) \mathrm{AVP}$ V1 antagonist (18). In our study, in contrast, forearm vasodilation was potentiated by pretreatment with the $\mathrm{V} 1$ receptor antagonist. V2 receptors have thus far been identified in both renal collecting duct and brain. The results of our present study strongly imply that AVP-mediated forearm vasodilation occurs independent of the brain V2 receptors. Our experimental design localizes the vasodilator V2 receptor to the forearm vasculature.

Vasopressin vasodilation is regionally selective. Although this study did not attempt to construct parallel forearm and finger blood flow dose-response curves, it is apparent that the effects of AVP are directionally dissimilar in the finger and forearm (Figs. 2 and 4). This effect was also noted in Kitchin's study, in which hand and forearm blood flow demonstrated directionally opposite changes in response to AVP (39). In contrast to skeletal muscle, digital arteries presumably are characterized by a larger population of $\mathrm{V} 1$ than $\mathrm{V} 2$ receptors, or the $\mathrm{V} 1$ receptors are more effectively coupled to their intracellular messenger. Although this study has examined the disparate responses of two regional circulations to AVP infusion, others have also reported that AVP causes regionally selective vasoconstriction $(48,52,53)$.

Liard et al. demonstrated the nonuniform regional vascular effect of AVP infusion alone or after V1 blockade $(38,48)$. Although this may be due to a heterogenous distribution of vasoconstrictor $\mathrm{V} 1$ receptors, other potential mechanisms have been identified. AVP potentiates baroreflexes and its pressor effects in animals are, indeed, significantly greater after sinoaortic denervation $(46,54)$. Withdrawal of sympathetic neural activity, however, need not be uniform across disparate vascular beds. AVP administration preferentially reduces renal sympathetic tone in some species (54). In addition, as noted above, AVP's effects on the release of EDRF are regionally selective (18). In any circulation, the net effect of AVP on blood flow may be the result of the balance of direct AVP V1 and V2 receptor effects, and the effect of AVP on sympathetic activity in that circulation.

Effect of AVP infusion on systemic hemodynamics. In this study, IA AVP administration elicited no pressor effect, and at $10 \mathrm{ng} / \mathrm{kg}$ per min alone and at $1.0 \mathrm{ng} / \mathrm{kg}$ per min during $\mathrm{V} 1$ antagonism was associated with a decline in diastolic blood pressure and rise in heart rate (Tables I, II, and IV). This may be due to the summation of AVP's vasoconstrictor and vasodilator actions on regional circulations. Schwartz et al. reported that systemic AVP administration during V1 antagonism caused no change in blood pressure, but increased heart rate (55). The administration to humans of the more selective V2 agonist dDAVP, however, lowers blood pressure and increases heart rate $(7,56)$. Thus, the modest changes that AVP causes in blood pressure may be due to a balance of V1- and V2-mediated effects on regional vascular resistance.

Physiologic significance. Significant forearm vasodilation was observed in this study at plasma concentrations that may have physiologic relevance. In the small population examined in this study, forearm vasodilation was noted at local plasma AVP concentrations of $100-200 \mathrm{pg} / \mathrm{ml}$. AVP may also cause significant forearm vasodilation at substantially lower plasma levels. It is notable that forearm blood flow tended to increase in our dose-response protocol at the $0.1-\mathrm{ng} / \mathrm{kg}$ per min infu- sion, when plasma levels were $\sim 70 \mathrm{pg} / \mathrm{ml}$. In a larger study population, this might well have reached statistical significance.

During nonstress states, when AVP levels are from 1.0 to $5.0 \mathrm{pg} / \mathrm{ml}$, AVP may exert its primary effects as an antidiuretic hormone. Moderate stress (e.g. exercise, nausea) may increase plasma AVP levels to the $20-50 \mathrm{pg} / \mathrm{ml}$ range $(25,26)$; at these levels, the V2 vasodilator effect may cause skeletal muscle vasodilation and, in concert with other endothelial, myogenic, and metabolic vasodilator stimuli may act to counterbalance sympathetic vasoconstriction. More profound stress (e.g., hypovolemic hypotension, surgical trauma, congestive heart failure) may increase AVP levels to the $50-500 \mathrm{pg} / \mathrm{ml}$ range, and the V1 vasoconstrictor effect on skin, splanchnic, and skeletal muscle may predominate $(23,24,27-30)$.

The topographical distribution of vasopressin V1 and V2 receptors in regional vascular beds is not known, nor is the regulation of these receptors in pathophysiologic states. AVP has approximately equal affinity for V1 and V2 receptors. Thus, in addition to renal hydroosmotic effects, vasopressin might serve as an important hormonal modulator of regional blood flow.

\section{Acknowledgments}

The authors would like to thank Dr. Stephen L. Swartz for performance of prostaglandin determinations; Dr. Karl Hofbauer (CibaGeigy, Basel, Switzerland) for providing the AVP V1 antagonist; both Kathleen Benfell and John Fanikos, Research Pharmacists of the Brigham and Women's Hospital Investigational Drug Service, for aid in drug preparation; and Ms. Donna MacDonald for preparation of the manuscript.

This study was supported by National Heart, Blood, and Lung Institute (NHLBI) grants HL-36348, HL-36568, and 5-T32-HL07609. Dr. Hirsch is a recipient of a fellowship from the American College of Chest Physicians. Dr. Dzau is an Established Investigator of the American Heart Association. Dr. Creager is a recipient of Research Career and Development Award HL-01768 from the NHLBI.

\section{References}

1. Altura, B. M., and B. T. Altura. 1977. Vascular smooth muscle and neurohypophyseal hormones. Fed. Proc. 36:1853-1860.

2. Monos, E., R. Cox, and L. H. Peterson. 1978. Direct effect of physiologic doses of arginine vasopressin on the arterial wall in vivo. Am. J. Physiol. 3:H167-H172.

3. Cowley, A. W., S. J. Switzer, and M. M. Guinn. 1980. Evidence and quantification of the vasopressin arterial pressure control system in the dog. Circ. Res. 46:58-67.

4. Schwartz, J., J.-F. Liard, C. Ott, and A. W. Cowley. 1985. Hemodynamic effects of neurohypophyseal peptides with antidiuretic activity in dogs. Am. J. Physiol. 249:H1001-H1008.

5. Liard, J.-F. 1986. Cardiovascular effects associated with antidiuretic activity of vasopressin after blockade of its vasoconstrictor action in dehydrated dogs. Circ. Res. 58:631-640.

6. Walker, B. R. 1986. Evidence for a vasodilatory effect of vasopressin in the conscious rat. Am. J. Physiol. 251:H34-H39.

7. Bichet, D. G., M. Razi, M. Lonergan, M. F. Arthus, V. Papukna C. Kortas, and J. N. Barjon. 1988. Hemodynamic and coagulation responses to 1-desamino[8-D-arginine] vasopressin in patients with congenital nephrogenic diabetes insipidus. $N$. Engl. J. Med. 318:881887. 
8. Bartlestone, H. J., and P. A. Nasmyth. 1965. Vasopressin potentiation of catecholamine actions in dog, rat, cat and rat aortic strip. Am. J. Physiol. 208:754-762.

9. Cowley, A. W., D. Merrill, J. Osborn, and B. J. Barber. 1984. Influence of vasopressin and angiotensin in baroreflexes in the dog. Circ. Res. 54:163-172.

10. Schmid, P. G., F. M. Abboud, M. G. Wendling, E. S. Ramberg, A. L. Mark, D. D. Heistad, and J. W. Eckstein. 1974. Regional vascular effects of vasopressin: plasma levels and circulatory responses. Am. J. Physiol. 227:998-1004.

11. Floras, J. S., P. E. Aylward, F. M. Abboud, and A. L. Mark. 1987. Inhibition of muscle sympathetic nerve activity in humans by arginine vasopressin. Hypertension (Dallas). 10:409-416.

12. Floras, J. S., P. E. Aylward, B. N. Gupta, A. L. Mark, and F. M. Abboud. 1987. Modulation of cardiovascular reflexes by arginine vasopressin. Can. J. Physiol. Pharmacol. 65:1717-1723.

13. Abboud, F. M., P. E. Aylward, J. S. Floras, and B. N. Gupta. 1986. Sensitization of aortic and cardiac baroreceptors by arginine vasopressin in mammals. J. Physiol. (Lond.). 377:251-265.

14. Guo, G. B., P. G. Schmid, and F. M. Abboud. 1986. Sites at which vasopressin facilitates baroreflex inhibition of lumbar sympathetic nerve activity. Am. J. Physiol. 251:H644-H655.

15. Zusman, R. M., and H. R. Keiser. 1977. Prostaglandin biosynthesis by rabbit renomedullary interstitial cells in tissue culture. Stimulation by angiotensin II, bradykinin, and arginine vasopressin. J. Clin. Invest. 60:215-223.

16. Dunn, M. J., J. F. Liard, and F. Dray. 1978. Basal and stimulated rates of renal secretion and excretion of prostaglandins $E_{2}, F_{1 a}$, and 13,14-dihydro-15-keto $F_{1 \mathrm{a}}$ in the dog. Kidney Int. 136-143.

17. Walker, L. A., A. R. Whorton, M. Smigel, R. France, and J. C. Frolich. 1978. Antidiuretic hormone increases renal prostaglandin synthesis in vivo. Am. J. Physiol. 235:F180-185.

18. Katusic, Z. S., J. T. Shepherd, and P. M. Vanhoutte. 1984. Vasopressin causes endothelium-dependent relaxations of the canine basilar artery. Circ. Res. 55:575-579.

19. Bunag, R. D., I. H. Page, and J. W. McCubbin. 1967. Inhibition of renin release by vasopressin and angiotensin. Cardiovasc. Res. 1:67-73.

20. Khokhar, A. M., J. D. H. Slaer, M. L. Forsling, and N. N. Payne. 1976. Effect of vasopressin on plasma volume and renin release in man. Clin. Sci. Mol. Med. 50:415-424.

21. Malayan, S. A., D. J. Ramsay, L. C. Keil, and I. A. Reid. 1980. Effects of increases in plasma vasopressin concentration on plasma renin activity, blood pressure, heart rate, and plasma corticosteroid concentration in conscious dogs. Endocrinology. 107:1899-1904.

22. Ebert, T. J., A. W. Cowley, and M. Skelton. 1986. Vasopressin reduces cardiac function and augments cardiopulmonary baroreflex resistance increases in man. J. Clin. Invest. 77:1136-1142.

23. Davies, R., M. L. Forsling, and J. D. H. Slater. 1977. The interrelationship between the release of renin and vasopressin as defined by orthostasis and propranolol. J. Clin. Invest. 60:1438-1441.

24. Johnston, C. I., M. Newman, and R. Woods. 1981. Role of vasopressin in cardiovascular homeostasis and hypertension. Clin. Sci. 61:129s-139s.

25. Landgraf, R., R. Hacker, and H. Buhl. 1982. Plasma vasopressin and oxytocin in response to exercise and during a day-night cycle in man. Endokrinologie. 79:S281-291.

26. Melin, B., J. P. Eclache, G. Geelen, G. Annat, A. M. Allevard, E. Jarsaillon, A. Zebidi, J. J. Legros, and C. I. Gharib. 1980. Plasma AVP, neurophysin, renin activity, and aldosterone during submaximal exercise performed until exhaustion in trained and untrained men. Eur. J. Appl. Physiol. 44:141-151.

27. Creager, M. A., A. T. Hirsch, S. S. Cutler, J. A. Majzoub, and V. J. Dzau. 1987. Vasopressin response to hypotension in normal subjects. Clin. Res. 271a. (Abstr.)

28. Rowe, J. W., R. L. Shelton, J. H. Helderman, R. E. Vestal, and
G. L. Robertson. 1979. Influence of the emetic reflex on vasopressin release in man. Kidney Int. 16:727-735.

29. Sorenson, P. S., and M. Hammer. 1985. Vasopressin in plasma and ventricular cerebrospinal fluid during dehydration, postural changes and nausea. Am. J. Physiol. (Reg. Int. Comp. Physiol.) 17:R78-R83.

30. Goldsmith, S. R., G. S. Francis, A. W. Cowley, T. B. Levine, and J. N. Cohn. 1983. Increased plasma arginine vasopressin in patients with congestive heart failure. J. Am. Coll. Cardiol. 1:1385-1390.

31. Erwald, R., and K.-L. Wiechel. 1978. Effect of vasopressin on central and splanchnic hemodynamics in awake man. Acta Chir. Scand. 144:347-358.

32. Aylward, P. E., J. S. Floras, W. N. Leimbach, and F. M. Abboud. 1986. Effects of vasopressin on the circulation and its baroreflex control in healthy men. Circulation. 73:1145-1154.

33. Majzoub, J. A., F. Carrazona, J. Shalman, K. Baker, and R. Emanuel. 1987. Defective regulation of vasopressin gene expression in Brattleboro rats. Am. J. Physiol. 252:E637-E642.

34. Swartz, S. L., G. H. Williams, N. K. Hollenberg, L. Levine, R. G. Dluhy, and T. M. Moore. 1980. Captopril-induced changes in prostaglandin production. Relationship to vascular responses in normal man. J. Clin. Invest. 65:1257-1264.

35. Bussein, J. P., B. Waeber, J. Nussberger, M. D. Schaller, H. Gavras, K. Hofbauer, and H. R. Brunner. 1984. Does vasopressin sustain blood pressure of normally hydrated healthy volunteers? Am. J. Physiol. 246:H143-H147.

36. Altura, B. M. 1973. Selective microvascular constrictor actions of some neurohypophyseal peptides. Eur. J. Pharmacol. 24:49-60.

37. Corliss, R. J., D. H. McKenna, S. Sialer, G. S. O'Brien, and G. G. Rowe. 1968. Systemic and coronary hemodynamic effects of vasopressin. Am. J. Med. Sci. 256:293-299.

38. Liard, J.-F., and J. C. Spadone. 1984. Hemodynamic effects of antagonists of the vasoconstrictor action of vasopressin in conscious dogs. J. Cardiovasc. Pharmacol. 6:713-719.

39. Kitchin, A. H. 1957. The effect of pitressin on hand and forearm blood flow. Clin. Sci. 16:639-644.

40. Manning, M., L. Balaspiri, J. Judd, M. Acosta, and W. H. Sawyer. 1974. Probing the molecular basis of antidiuretic specificity and duration of action of synthetic peptides. FEBS (Fed. Eur. Biochem. Soc.) Lett. 44:229-232.

41. Manning, M. 1982. Antagonists of vasopressor and antidiuretic responses to arginine vasopressin. Ann. Int. Med. 96:520-522.

42. Manning, M., and W. H. Sawyer. 1985. Development of selective agonists and antagonists of vasopressin and oxytocin. In Vasopressin. R. W. Schrier, editor. Raven Press, New York. 131-144.

43. Moses, A. M., and E. Steciak. 1986. Urinary and metabolic clearances of arginine vasopressin in normal subjects. Am. J. Physiol. 251:R365-R370.

44. Richardson, D. W., and A. G. Robinson. 1985. Desmopressin. Ann. Int. Med. 103:228-239.

45. Vilhardt, H., S. Lundin, and J. Falch. 1986. Plasma kinetics of DDAVP in man. Acta Pharmacol. Toxicol. 58:379-381.

46. Montani, J.-P., J.-F. Liard, J. Schoun, and J. Mohring. 1980. Hemodynamic effects of exogenous and endogenous vasopressin at low plasma concentrations in conscious dogs. Circ. Res. 47:346-355.

47. Liard, J.-F., O. Deriaz, P. Schelling, and M. Thibonnier. 1982. Cardiac output distribution during vasopressin infusion or dehydration in conscious dogs. Am. J. Physiol. 243:H663-H669.

48. Liard, J.-F. 1986. Effects of intra-arterial arginine-vasopressin infusions on peripheral blood flows in conscious dogs. Clin. Sci. 71:713-721.

49. Wang, B. C., W. D. Sundet, M. O. K. Hakumaki, and K. L. Goetz. 1983. Vasopressin and renin responses to hemorrhage in conscious, cardiac-denervated dogs. Am. J. Physiol. 245:H399-H405.

50. Andrews, C. E., and B. M. Brenner. 1981. Relative contributions of arginine vasopressin and angiotensin II to maintainance of 
systemic arterial pressure in the water-deprived rat. Circ. Res. 48:254258.

51. Laycock, J. F., W. Penn, D. G. Shirley, and S. J. Walter. 1979. The role of vasopressin in blood pressure regulation immediately following acute haemorrhage in the rat. J. Physiol. (Lond.). 296:267-275.

52. Hofbauer, K. G., W. Studer, S. C. Mah, J.-B. Michel, J. M. Wood, and R. Stalder. 1984. The significance of vasopressin as a pressor agent. J. Cardiovasc. Pharmacol. 6:S429-S438.

53. Liard, J.-F. 1987. Does vasopressin-induced vasoconstriction persist during prolonged infusion in dogs? Am. J. Physiol. 252:R668R673.
54. Undesser, K. P., E. M. Hasser, J. R. Haywood, A. K. Johson, and V. S. Bishop. 1985. Interactions of vasopressin with the area postrema in arterial baroreflex function in conscious rabbits. Circ. Res. 56:410-417.

55. Schwartz, J., L. C. Keil, J. Maselli, and A. Reid. 1983. Role of vasopressin in blood pressure regulation during adrenal insufficiency. Endocrinology. 112:234-238.

56. Derkx, F. H. M., A. J. Man In't Veld, R. Jones, J. L. Reid, and M. A. D. H. Schalenkamp. 1983. DDAVP (1-desamino-8-D-arginine vasopressin): an antagonist of the pressor action of endogenous vasopressin. J. Hypertens. 1(Suppl. 2):58-61. 